\title{
Novo método de tratamento da superfície de implantes diminui a proliferação bacteriana
}

Infecções ao redor de implantes recém instalados não constituem um problema que afeta apenas os implantes osseointegrados, que receberão cargas protéticas, e os implantes ortodônticos (microparafusos e miniplacas de titânio). Na Ortopedia, 1 a $5 \%$ das próteses de quadril são acometidas por infecções hospitalares, o que resulta na perda de uma parcela das próteses instaladas. A infecção pode ser agravada pela dificuldade de levar o antibiótico à região sem o auxílio de uma administração endovenosa. Com o objetivo de produzir implantes que possuam uma superfície biologicamente ativa que previna a infecção periprotética, pesquisadores da Filadélfia desenvolveram um método de ligar a vancomicina ao titânio*. Seus achados foram publicados na revista Clinical Orthopedics and Related Research de dezembro de 2004 e receberam um prêmio internacional pelo feito. Inicialmente, o antibiótico foi ligado covalentemente à superfície do implante e a eficiência deste método foi comprovada através de espectofotometria. A seguir, testes de proliferação bacteriana atestaram a capacidade bactericida da superfície tratada. Uma vantagem adicional dessa abordagem é que ela continua permitindo a esterilização da peça por calor ou radiação. Os autores discutem que esse método pode ser levemente modificado para permitir a ligação de peptídeos ao titânio, tais como fatores de crescimento. Essa nova tecnologia detém um grande potencial de aplicações e, provavelmente, pode ser ajustada para a Odontologia. Neste cenário, poderíamos aumentar ainda mais o sucesso dos implantes protéticos e ortodônticos hoje utilizados ao diminuir a infecção perimplantar ou incrementar a taxa de osseointegração pela adição de fatores de crescimento.

* PARVIZI, J. et al. Titanium Surface with Biological Activity against Infection. Clin Orthop Relat Res, Philadelphia, n. 429, p. 33-38, dez. 2004.

\section{Descoberto importante fator que influencia a morfologia dentária}

Estudos da evolução de mamíferos freqüentemente utilizam dados provenientes da dentição. As características dentárias são particularmente importantes para a inferência das relações filogenéticas (grau de parentesco entre espécies) na taxonomia de fósseis, dos quais apenas os dentes são usualmente recuperados. $\mathrm{O}$ uso da morfologia do dente como sinal filogenético implica em características dentárias independentes entre si. Por exemplo, o número de cúspides, idealmente, não deveria estar associado com a altura das mesmas, com o tamanho do dente, ou a existência de cristas de esmalte. Assim, fósseis que exibam cúspides mais altas que outros de um diferente sítio arqueológico poderiam ser compreendidos como pertencentes a um diferente braço evolutivo. Nós já sabemos que existem traços quantitativos dentários que são hereditários, mas a maioria das mutações genéticas conhecidas com efeitos na dentição é relacionada à falta parcial ou total dos dentes, e não traz informação da morfologia dentária. Para lançar alguma luz sobre esse assunto, pesquisadores da Universidade de Helsinki, na Finlândia, publicaram um artigo no fascículo de 11 de novembro de 2004 na revista Nature**. Eles analisaram como diferentes níveis de uma proteína sinalizadora celular, a ectodisplasina (Fig. 1), impactava nas características e desenvolvimento dentários. Dentes de duas linhagens de ratos mutantes foram comparados com dentes de ratos normais. Uma das linhagens mutante não possuía a ectodisplasina funcional. Essa característica em humanos causa a Síndrome da Displasia Ectodérmica Hipohidrótica ligada ao cromossomo X, e o fenótipo dentário de ratos e humanos é muito similar. A outra linhagem mutante, um rato transgênico, tinha uma expressão da ectodisplasina acima do normal. Os resultados do trabalho mostraram que

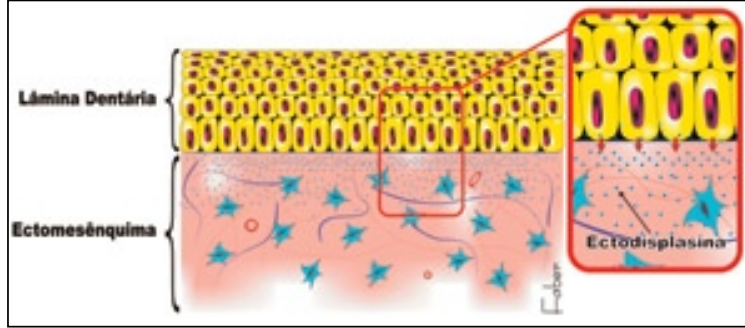

FIGURA 1 - A ectodisplasina pertence à família de proteínas denominadas Fator de Necrose Tumoral (TNF). Ela é uma proteína de membrana que, ao ser clivada, se torna livremente difundível no espaço extracelular. A proteína é expressa na lâmina dentária e se difunde para o ectomesênquima (ver detalhe).

diferentes sinalizações dessa proteína alteram a forma dentária para além das variações que são tipicamente encontradas dentro de uma espécie, ou mesmo um gênero. Quanto maior a expressão de ectodisplasina, maiores são: o número de dentes, o dente em si (no sentido buco-lingual), e o número de cúspides. Esses resultados sugerem que a maior parte dos aspectos da forma do dente potencialmente evoluem de maneira correlacionada. Do ponto de vista ortodôntico esses resultados também possuem relevância. É possível que pequenas variações que tenham ocorrido na expressão da ectodisplasina durante o desenvolvimento dentário de nossos pacientes, promovam fenótipos dentários que predisponham ou não o indivíduo a possuir uma excelente intercuspidação dentária. Entretanto, pesquisas ainda são necessárias para avaliar essa hipótese.

** KANGAS, A., et al. Nonindependece of mammalian dental characters. Nature, London, v. 432, v. 432, p. 211-214.

Essa seção é realizada pelo Dr. Jorge Faber, Doutor em Biologia Animal, Laboratório de Microscopia Eletrônica - UnB e Mestre em Ortodontia - UFRJ (jorgefaber@terra.com.br). Envie suas sugestões e opiniões para o e-mail dental@dentalpress.com.br. 